\title{
Letter from the Editor-in-Chief
}

\section{Peter G. M. de Jong ${ }^{1}$}

Published online: 9 August 2019

(C) International Association of Medical Science Educators 2019

Welcome to the third issue of Medical Science Educator of 2019. This issue features almost 40 new manuscripts reporting on medical education, which I hope will be of interest to you.

At the IAMSE Annual Meeting in Roanoke, VA, the Editorial Board delivered two workshops for our journal reviewers, a basic level and an advanced level reviewer workshop. Both sessions were well attended, and good discussions about the valuable work reviewers do for our journal came up. In case you are a member of IAMSE and want to become one of our reviewers, please contact us at journal@iamse.org and we will connect with you.

Also at the Roanoke meeting, we announced the winner of the 2019 Outstanding Reviewer award. This year the award was won by Dr. Nagaswami Vasan. This award is an initiative of the Editorial Board to recognize one of the journal's reviewers for his/her outstanding peer review efforts over the past year. The recipients are selected based on several criteria including reviewer performance and delivering the reviews in a timely manner. This year Dr. Vassan performed very well as a reviewer, and the Editorial Board is pleased to name him the 2019 award recipient.

I am very happy and excited to see that so many educators find their way to Medical Science Educator to present their scholarly work. I hope you will enjoy this issue and that you will continue supporting Medical Science Educator both as a reader and as an author of your own scholarly work for the benefit of our work and the work of others!

Peter G.M. de Jong, PhD

Editor-in-Chief

Publisher's Note Springer Nature remains neutral with regard to jurisdictional claims in published maps and institutional affiliations.

Peter G. M. de Jong

P.G.M.de_Jong@lumc.nl

1 Leiden University Medical Center, Leiden, The Netherlands 